\title{
Comparação de narrativas sobre Canudos na perspectiva da história dos saberes psicológicos
}

\author{
Narratives comparison about Canudos in the perspective of the history \\ of the psychological knowledges
}

\author{
Gabriela Daud Bollela \\ Universidade de São Paulo - Ribeirão Preto \\ Marina Massimi \\ Instituto de Estudos Avançados - Universidade de São Paulo \\ Brasil
}

\begin{abstract}
Resumo:
O objetivo do artigo é comparar duas narrativas acerca de um evento histórico à luz da história dos saberes psicológicos: o movimento de Canudos liderado por Antônio Conselheiro. As narrativas comparadas são: a interpretação dada por Euclides da Cunha acerca das características psicológicas dos participantes desse movimento, em Os Sertões; e os relatos acerca das experiências subjetivas vivenciadas em narrativas orais de sobreviventes de Canudos, colhidas por Odorico Tavares. As duas fontes, produzidas em diferentes gêneros literários (literatura e memória oral) focam as vivências dos participantes de Canudos, divergindo na forma como foram colhidas: a primeira por um observador externo e escritor interprete da visão cultural da intelectualidade brasileira da época; a segunda, expressão narrativa dos atores do movimento entrevistados. Os lugares-comuns evidenciados em ambas as narrativas foram analisados à luz dos respectivos universos histórico-culturais. As divergências emergentes são relacionadas a teorias e saberes psicológicos inerentes a esses universos.
\end{abstract}

Palavras-chave: Canudos; Euclides da Cunha; história dos saberes psicológicos; vivências da temporalidade.

\begin{abstract}
:
The objective of the article is to compare two narratives about a historical event in the light of the history of psychological knowledge: the Canudos movement led by Antônio Conselheiro. The narratives to be compared are: the interpretation given by Euclides da Cunha about the psychological characteristics of the participants of this movement, presented in his novel "Rebellion in the Backlands"; and the reports about the subjective experiences through oral narratives of survivors from Canudos, collected by Odorico Tavares. The two sources, produced in different literary genres (literature and oral memory) focus on the experiences of Canudos participants, diverging in the way they were collected: the first one by an external observer and writer, representative of the cultural vision of the Brazilian intellectuals of the time; the second one, narrative expression of the actors of the movement who were interviewed. The "common places" shown in both narratives were analyzed in the light of each respective historical-cultural universes. The emerging
\end{abstract}


divergences are related to theories and psychological knowledge inherent in these universes.

Keywords: Canudos; Euclides da Cunha; History of the psychological knowledge; Temporality experiences.

\section{Introdução}

A Guerra de Canudos foi um dos eventos que evidenciaram a instabilidade do período político pós proclamação da República (Carvalho, 1987), já que a comunidade não reconhecia a legitimidade de um governo que sistematicamente os excluía. Aqueles que aderiram ao movimento promovido por Antônio Conselheiro, parte da população mais pobre, nordestina e descendentes de ex escravos, constituíram uma comunidade autônoma, a qual seguia uma tradição inspirada no catolicismo pós tridentino (Campos \& Claro, 2012). Os coronéis da região, o Governo Federal e as próprias hierarquias eclesiásticas consideravam a comunidade de Canudos uma ameaça, visto que não se submetia ao controle institucional (Campos \& Claro, 2012), de modo que o poder público veio a organizar quatro expedições militares que atacaram e, por fim, invadiram o arraial de Belo Monte (Mota \& Braick, 2012). Devido à atenção que o conflito ganhou, intelectuais contemporâneos ao fenômeno interessaram-se por ele, tal como o jornalista Euclides da Cunha, que acompanhou as expedições militares. Após sua experiência junto ao exército, Euclides escreveu o icônico romance Os Sertões (2015) relatando os acontecimentos presenciados durante o tempo em que acompanhou o exército, à luz de suas observações de testemunho presencial, mas também de sua visão de mundo. Neste âmbito, faz uso das ciências da época, dentre elas a psicologia e a psiquiatria, aplicando-as à consideração desse fenômeno social e político.

Após a vitória do governo republicano sobre os sertanejos, buscou-se denegrir a imagem dos canudenses e do seu líder, Conselheiro, de modo a justificar o massacre e a mascarar tanto os fatores da violenta exclusão social e política quanto as exigências de participação e enraizamento cultural/religioso que efetivamente contribuíram para a formação do arraial (Campos \& Claro, 2012).

Este artigo busca discutir o uso de categorias referentes às vivências psicológicas dos participantes do movimento de Canudos, a partir de ambos depoimentos dos próprios canudenses e da narrativa euclidiana de Os Sertões a fim de verificar as diferentes perspectivas acerca do fenômeno que eventualmente 
poderiam existir quanto às categorias empregadas ${ }^{1}$. A compreensão das categorias utilizadas por essas narrativas é possibilitada pelos estudos históricos acerca dos saberes psicológicos difundidos no Brasil ao longo do período colonial e do século XIX.

Por sua vez, é importante compreender que as categorias médicas e psicológicas utilizadas na análise de Os Sertões encontram-se inseridas na perspectiva própria dos intelectuais da época, visando a construção de um Brasil moderno e pautado na ciência. À luz dessa perspectiva, seria preciso reduzir e possivelmente eliminar todas as dissonâncias evidentes na multifacetada sociedade brasileira, através da imposição de uma norma comum, utilizando os conhecimentos das ciências médicas, sociais e psicológicas para estabelecer tal padrão de normalidade (Costa, 1979; Machado e colaboradores, 1978; Serpa Jr., 1998 citado por Augusto \& Ortega, 2011; Oda, 2000; Ventura, 1997). A compreensão dessas categorias é possibilitada pelos estudos históricos acerca das origens da Psiquiatria e da Psicologia Cientifica no Brasil dos séculos XIX e XX.

Considerando um horizonte historiográfico mais amplo, o confronto entre dois diferentes universos culturais, o dos canudenses e o de Euclides da Cunha, quanto à interpretação do fenômeno da comunidade de Canudos, parece-nos refletir também o embate entre duas diferentes vivências do tempo e da história, segundo a perspectiva assinalada por François Hartog através do conceito de regimes de historicidade: haveria uma vivência do tempo, ou temporalidade, pautada na referência ao passado e à tradição, no caso dos Canudenses; e outra vivência do tempo, pautada nos ideais do progresso e do moderno, voltada portanto ao futuro, no caso de Euclides.

\section{Método}

Este estudo tem cunho histórico e tem por base o levantamento e a análise de três fontes primárias, descritas a seguir.

\section{Listagem das Fontes Primárias:}

1) Tavares, O. \& Verger, P. (1947, julho 19). Roteiro de CanudosI e II: O Reduto de Antônio Conselheiro. Revista O Cruzeiro. 0039 (3).

\footnotetext{
${ }^{1}$ Os depoimentos foram em parte colhidos por Odorico Tavares e publicados na revista Cruzeiro de 1947; em parte registradas no memorial do sobrevivente Honório Vilanova Apesar do trabalho de Odorico Tavares não ser uma publicação científica, essa matéria inspirou a iniciativa posterior de estudiosos que buscaram resgatar a visão dos sobreviventes a fim de compor a narrativa sobre Canudos.
} 
Trata-se de duas reportagens publicadas pela revista O Cruzeiro. Nelas encontram-se as entrevistas realizadas e divulgadas com os sobreviventes ao massacre de Canudos, fazendo parte de um acervo digital de todas as edições da revista O Cruzeiro.

2) Macedo, N. (1929). Memorial de Vilanova. Rio de Janeiro: O Cruzeiro. Trata-se de um livro de aproximadamente 160 páginas contendo relatos das memórias de Honório Vilanova, sobrevivente da guerra de Canudos e irmão de Antônio Vilanova, um dos principais líderes conselheiristas.

3) Euclides da Cunha. Os Sertões. 14a edição, Rio de Janeiro, Record, 2015.

A partir da leitura exaustiva dos depoimentos dos sobreviventes contidos nas duas primeiras fontes e do romance Os Sertões buscou-se identificar temas recorrentes nos depoimentos (lugares comuns), ou seja, temas abordados direta ou indiretamente em ambas fontes. Uma vez identificados tais temas, uma unidade de significado (considerada como uma "categoria") foi atribuída a cada um, de modo a abarcar o tema tanto no depoimento dos sobreviventes quanto no texto de Euclides.

Os lugares comuns, ou tópicos, evidenciados e a partir dos quais desenvolveremos nossa análise comparativa, são: o misticismo do Conselheiro; o valor da terra e de seus recursos; as características da população de Canudos; a representação de Conselheiro, especialmente seu caráter de peregrino; a relação social dos Canudenses com Conselheiro, incluindo as interações entre ele e as mulheres; e relações de cooperação entre os Canudenses.

Em seguida, buscou-se contextualizar esses tópicos, por um lado, no universo histórico cultural constituído pela visão de homem e de mundo de Euclides da Cunha e do pensamento em vigor no mundo intelectual brasileiro na época; e, por outro, no universo histórico cultural constituído pelas tradições de proveniência dos canudenses, especificamente quanto ao "bem viver" e ao "bem comum", colhendo os possíveis indícios da influência de matrizes culturais e religiosas ligadas a presença, naquele território, de jesuítas, índios, comunidades de escravos, etc.

A contextualização das fontes nos universos históricos de produção, permitiu proceder para responder ao objetivo da pesquisa, ou seja, verificar a presença de teorias e saberes psicológicos na formulação das categorias usadas por Euclides para narrar os fenômenos sociais por ele observados e das categorias usadas pelos canudenses para narrar as experiências vivenciadas; e evidenciar as eventuais 
diferenças.

\section{Contextualização histórica}

\section{O universo sociocultural de Euclides da Cunha}

Os dados da biografia de Euclides da Cunha revelam como sua formação foi influenciada pelas teorias antropológicas, sociológicas e psicológicas em voga na época.

Euclides, nascido em 1866 em uma família de classe média, aos 20 anos ingressa na Escola Militar da Praia Vermelha- um dos centros de irradiação de ideias positivistas- pois escolas militares possibilitavam a formação acadêmica de pessoas não tão abastadas quanto as elites (Ventura, 1996). Foi aluno de Benjamin Constant e no período em que lá esteve se afeiçoou muito aos ideais republicanos, posicionamento que manteve até a vida adulta, durante o período em que escreveu para $O$ Estado de São Paulo denunciando o governo monárquico (Ventura, 1996). Essa postura se justificava, pois de acordo com Ventura (1996, p. 277), Euclides "acreditava ser inevitável a passagem da monarquia à República. Sua formação positivista e evolucionista o levava à crença fatalista em uma série linear de etapas do desenvolvimento humano". Nesse momento histórico, o governo republicano era considerado o modelo mais progressista da época, inspirado na Revolução Francesa, movimentando a vanguarda contra a monarquia obsoleta (Ventura, 1996). Desse modo, a influência europeia acarretou a importação de ideias e formas de compreender o mundo, incorporando as teorias raciais que serão abaixo descritas.

A crença política de Euclides na República era, segundo Moura (1964), um idealismo romântico: a República por ele idealizada não era o efetivo regime iniciado no Brasil desde 1889, mas sim uma construção, moldada pelos ensinamentos que teve na Escola Militar. Inclusive a isto se deve a frustração com o regime republicano, responsável pela chacina que ele presencia em Canudos. Tal idealização da República o levará a acreditar que no Brasil se instaurara uma distorção de regime republicano, distorção correlacionada com as pessoas, o clima e o território inferior ao da Europa, sendo essas condições responsáveis por degradar o regime republicano que seria, em sua essência, perfeito. De qualquer forma, a crença republicana leva Euclides a considerar o regime comunitário canudense inspirado num passado que deve ser rechaçado e superado o mais rapidamente possível. 
No entanto, apesar de encontrar-se mergulhado nos pressupostos advindos do meio cientificista, Euclides traz ao longo de toda a sua produção intelectual um conflito. Apesar de ter desenvolvido atividades intelectuais diversas, mesmo antes de escrever e publicar Os Sertões é possível perceber a importância dada por ele em compreender a questão da identidade nacional brasileira. Isso aparece em suas crônicas, poemas e cartas, as quais revelam outras faces de sua produção (Oliveira, 2002). Sua visão de mundo, portanto, não foi apenas influenciada pelos pressupostos positivistas com os quais teve contato na academia, mas sim conviveu com o sentimento de um romantismo explícito, que encontra como refúgio a imagem idílica do sertão.

Tal idealização da natureza como refúgio são encontradas nas publicações de sua juventude, tal como o texto Em viagem, veiculado pelo jornal O Democrata, de abril de 1889, o qual mostra o autor exaltando a beleza natural em detrimento do progresso urbano e industrial:

É majestoso o que nos rodeia $-[\ldots]$, a natureza ergue-se brilhante e sonora sublime de canções, auroras e perfumes [...]. Em seguida, o autor completa: "contudo uma ideia triste nubla-me este quadro grandioso - lançando para a frente o olhar, avisto ali, curva sinistra, entre o claro azul da floresta, a linha da locomotiva, como uma ruga fatal na fronte da natureza [...] (Cunha, 1966, p. 517).

A descrição do cenário natural pode exemplificar a fala do jovem Euclides, exaltando a natureza bela e pura, sendo a preservação de tal pureza a justificativa para que fosse contrário às realizações da sociedade industrial.

Já em seu poema $A$ cruz da estrada, de 1884, pode-se perceber uma grande diferença entre a descrição feita pelo autor sobre o sertão. Enquanto no poema, ilustrado a seguir, o sertão aparece como uma representação natural mística, abundante e de encontro com Deus, em Os Sertões a terra se torna assustadora, assolada pela escassez causada pela seca.

Se vagares um dia nos sertões, Como hei vagado - pálido, dolente Em procura de Deus - da fé ardente Em meio das solidões...

Se fores, como eu fui, lá onde a flor Tem do perfume a alma inebriante, Lá onde brilha mais que o diamante A lágrima da dor...

Se sondares da selva a entranha fria Aonde dos cipós na relva extensa Noss'alma embala a crença. (...) (Cunha, 1884, p. 637). 
Diante disso, Oliveira (2002) analisa a forma com que Euclides, apesar de muito influenciado pelo meio intelectual em que viveu, expressava uma inerente contradição a respeito dos componentes que constituem a identidade nacional. Em determinado momento, sua visão considerava o sertão um cenário idílico e romântico, o qual seria uma das formas de expressão dessa identidade (uma natureza pura). Além disso, através de sua formação, o autor também absorve a concepção de nação republicana, sendo que para ele a nação seria equivalente à República, entendida como o ápice do desenvolvimento do país. Ambas visões românticas, idealizadas e conflitantes seriam posteriormente estilhaçadas após presenciar a Guerra de Canudos.

A pedido do jornal $O$ Estado de São Paulo, Euclides é enviado como correspondente ao sertão baiano por quase 2 meses para acompanhar a expedição militar contra os canudenses, em 1897. Considerando o patriotismo do autor e seu expresso fascínio pelo sertão, é possível supor que a proposta foi atraente, permitindo que presenciasse a ação do exército republicano dentro do cenário que antes ocupava suas fantasias. Contudo, a realidade se apresentou de forma crua: o sertão que antes era cenário puro e místico, após vivenciar a realidade da guerra tornou-se bárbaro e escasso. Ao mesmo tempo, a república idealizada e justa logo se mostra autoritária e sanguinária, não hesitando em ceifar a vida dos sertanejos que haviam se entregado. Desse modo, o desencanto que já havia despontado pouco antes de viajar à Canudos, se consolida em Euclides, tornando-o cético de que poderiam existir utopias de progresso (Oliveira, 2002).

Considerando estes pontos, Oliveira (2002, pp. 517-518) aborda em sua análise, que a própria obra d'Os Sertões acaba servindo como um "profundo exame de consciência coletiva" que o autor faz a fim de elaborar os conflitos entre suas vivências e as referências (cientificistas, positivistas, etc.) oferecidas para a interpretação da realidade naquele momento. Desse modo, o livro materializa o grande conflito: Apesar de buscar Euclides busca os valores que estruturariam a brasilidade e a nação brasileira, mesmo baseado em construções cientificistas, mas, no momento em que escreve o livro, há o grave reconhecimento de que a república (elemento que até então era sinônimo de nação) havia se tornado o algoz dos brasileiros. Desse modo, é possível dizer que durante toda a sua vida intelectual, o escritor foi atormentado pela impossibilidade de conciliar essas visões, elemento que o manteve tão envolvido no próprio trabalho que fez com que negligenciasse sua vida pessoal, incluindo o próprio casamento. Isso fez com que sua relação com a esposa se tornasse cada vez mais distante, de modo que esta acabou por buscar 
um amante. Euclides, quando descobriu, foi morto no confronto com este, trazendo um trágico fim à vida do escritor, em 1909.

Diante de tal contexto, é relevante analisar em detalhes quais foram as referências teóricas que tanto permearam o pensamento do autor, a ponto de suscitar tal conflito. Moura (1964) também explicita que houveram inúmeras mudanças e influências contraditórias que a obra e o pensamento de Euclides sofreram, contrapondo as teorias europeias de cunho racista com a realidade que ele teve chance de observar em Canudos. A análise de Moura (1964) diz respeito às principais leituras realizadas por Cunha que tiveram influências sobre sua abordagem ao fenômeno de Canudos: o antropogeografismo de F. Ratzel, a antropologia médica de G. V. Lapouge e C. Lombroso, a interpretação dos conflitos raciais de L. Gumplowicz, o positivismo de Augusto Comte e o evolucionismo de Herbert Spencer.

O etnólogo e geólogo alemão Friedrich Ratzel (1844-1904) propunha o determinismo geográfico ou antropogeografismo. Ratzel criara o conceito de Lebensraum, ou "espaço vivo", que relaciona grupos humanos com as unidades espaciais onde eles se desenvolvem². Esta foi uma das teorias de base de Os Sertões: de fato, Euclides opta por dividir a obra nos capítulos referentes à Terra e ao Homem, denotando a preferência por estudar fenômenos sociais através da influência do meio físico (Moura, 1964).

A leitura das obras do antropólogo francês Georges Vacher de Lapouge (1854-1936) e do médico italiano Cesare Lombroso (1835-1909) sugeriu a Euclides algumas hipóteses interpretativas a respeito dos canudenses (Moura, 1964). Lapouge era um evolucionista convicto, persuadido de que o destino do mundo dependeria da vitória dos arianos sobre os judeus, conforme a obra $O$ ariano, o seu papel social (1889-1890), inspiradora do antissemitismo nazista. Lapouge acreditava na importância do fator racial na evolução da civilização e nesta perspectiva insistia quanto à inferioridade psicológica e fisiológica dos mestiços e quanto ao risco da extinção da raça causado pelos cruzamentos entre diversas raças humanas (Bolsanello, 1996). A teoria antropológica de De Lapouge acerca da existência da superioridade da raça branca sobre as demais dava respaldo à visão de Euclides de que os negros, indígenas e mestiços que habitavam Canudos fossem naturalmente propensos à degeneração física e mental.

\footnotetext{
2 Dentre as obras de Ratzel que tratam dos conceitos mencionados, temos as seguintes referências: Ratzel, F. Völkerkunde (1885-88); The History of Mankind, (1896-98). In Anthropogeographie (vol. 1, 1882, and vol. 2, 1891); Die Erde und das Leben: Eine vergleichende Erdkunde (190102), Politische Geographie (1897), "Lebensraum" (1901).
} 
Por sua vez, Cesare Lombroso criara a área denominada de Antropologia Criminal, onde sobressaia-se a teoria de que pelo exame anatômico-fisiológico dos criminosos poder-se-ia descobrir as causas da criminalidade, ligando-se o fator biológico à etiologia do crime. Em 1876, Lombroso publicou o livro O Homem Delinqüente, considerado como constitutivo da antropologia criminal. Nele o autor organizou uma série de dados sobre deformações físicas e anomalias de criminosos, empregando técnicas e procedimentos avaliativos como a frenologia. Com base em muitos dados antropométricos coligidos, fundamentou suas conclusões acerca da constituição de um criminoso (Bulferetti, 1975). De Lombroso, Euclides incorpora a abordagem genética, a qual diz respeito a uma tendência comportamental correlacionada às características físicas dos indivíduos. Haveria uma tendência inata de negros e mestiços para comportamentos criminosos e violentos devido à uma herança genética perceptível pela sua cor de pele e traços físicos (Santos, 2012).

O sociólogo polonês Ludwig Gumplowicz (1838-1909) considerava as raças como sendo determinadas socialmente, porém em constante conflito entre elas, sendo regidas por leis naturais (uma sorta de evolucionismo social) (Moura, 1964). A teoria de Gumplowicz complementava a análise euclidiana trazendo a noção de que no sertão brasileiro existiriam conflitos entre raças em busca de dominação.

Outra importante influência recebida por Euclides através das leituras realizadas em seu percurso de formação e assinalada por Moura (1964) é a de Auguste Comte (1798-1857). O pensamento do autor de Os Sertões foi tão profundamente moldado pela da filosofia positivista, que permeou inclusive sua busca por estabelecer parâmetros objetivos para compreender a experiência vivida em Canudos e na forma de registrar os dados, de maneira documental, semelhante a um relatório científico a fim de conferir credibilidade à obra literária. Isso pois o positivismo valoriza apenas a ciência objetiva e neutra como forma de construção de conhecimento válida. Em última instância, o procedimento rigoroso e metódico ao qual submete a escrita do seu livro explicita que tinha o intuito de comprovar se o ambiente explicava ou não o comportamento daquelas pessoas. A visão comtiana que inspira Euclides faz com que a confiança exclusiva no método cientifico para o conhecimento fidedigno dos fenômenos e a concepção de que os saberes míticos, religiosos e metafísicos seriam fases anteriores da evolução humana já superadas pela ciência. De fato, Euclides considera as concepções e práticas religiosas dos moradores de Canudos como um retrocesso, como resquícios de um tempo passado a ser superado pela marcha do progresso.

O evolucionismo social de Herbert Spencer (1820-1903) é outro referencial teórico utilizado por Cunha. As supostas diferentes raças humanas estariam 
submetidas a uma seleção natural e dessa seleção as espécies/raças superiores prosperariam e as inferiores sofreriam das mazelas sociais, tais como a pobreza (Souza \& Galvão, 2007). Sua visão é incorporada por Euclides, compondo a visão etnocêntrica a respeito do fenômeno em Canudos no que diz respeito às questões raciais e de determinismo tanto genético quanto ambiental ${ }^{3}$.

Em suma, o estudo de Moura (1964) acerca da formação intelectual de Euclides da Cunha evidencia as leituras que moldaram o arcabouço teórico inspirador do olhar e da escrita desse autor ao se deparar com o fenômeno de Canudos. Através dessas leituras, Cunha absorveu as teorias antropológicas, sociológicas e psicológicas por elas veiculadas que diziam respeito às problemáticas inerentes a população de Canudos e seus aspectos psicossociais.

O significado das categorias empregadas por Euclides para definir os Canudenses e a personalidade de seu líder, Antônio Conselheiro, pode ser melhor compreendido investigando o vocabulário proporcionado pelas teorias psicológicas difundidas no Brasil da época. Estas foram amplamente utilizadas no debate de teor político e sociológico acerca da composição racial da população brasileira, desencadeado após a abolição da escravatura. Para compreender a ótica em que foi tomada a população canudense na interpretação de Euclides, é preciso adentrar um pouco neste debate.

Uma das grandes questões em pauta era o caráter mestiço dessa população. Conforme assinala Skidmore (1989) no contexto brasileiro, o termo mestiço significa sangue misturado e poderia incluir qualquer mistura racial de sangue, índio, africano e europeu. As concepções vigentes entre os abolicionistas brasileiros do século XIX utilizavam-se da teoria evolucionista para afirmar que, nessa mistura, o elemento branco prevaleceria gradualmente se sobressaindo sobre os demais, devido a sua 'superioridade'. Desse modo, propunham uma teoria de 'branqueamento' da população brasileira e estimulavam uma política imigratória e social que favorecesse este processo.

O postulado do determinismo que já vimos perpassar muitas das leituras de Euclides assumira no Brasil um cunho racial. No século XIX, a tradicional teoria do determinismo racial que fundamentara o racismo na Europa e no Brasil do século XVIII, baseada na aparentemente superada teoria poligenista ${ }^{4}$, persistia numa roupagem evolucionista sendo difundida em discursos alicerçados pelas ciências

\footnotetext{
3 Moura (1964) mostra que mesmo sendo influenciado pelo evolucionismo como abordagem metodológica, Euclides não era um spenceriano ortodoxo, mas foi permeável à outras teorias, visto que diversos autores influenciaram seu pensamento.

${ }^{4}$ Vide por exemplo Gobineau, A. Essai sur l'inegalité dês Races Humaines, 1853-1855.
} 
humanas recém surgidas, tais como a psiquiatria, a psicologia, a sociologia 5 . Dentro da perspectiva do determinismo racial, a mestiçagem era considerada uma dupla ameaça: à sobrevivência, por causar infertilidade; e à capacidade psíquica dos indivíduos, por produzir homens degenerados e incapazes de perfectibilidade (Moreira, 1868). Essa posição caracterizava na época os debates acerca da identidade nacional no processo de formação do Brasil como Estado moderno.

A presença maciça de pessoas negras, herança do sistema escravista, constituía-se em mais um problema a ser enfrentado na visão desses intelectuais: diversas teorias raciais estigmatizavam a raça negra como sendo inferior no que diz respeito às qualidades físicas, psíquicas e morais ${ }^{6}$. Um dos alicerces da ideologia racista foi elaborado na França do século XIX pelo conde Arthur de Gobineau (1853/1933). A tese de Gobineau sustentava o declínio das civilizações, com base numa causa única que regeria a ascensão e a decadência: a degenerescência da raça, causada pela mistura de sangue, sendo que na mistura sempre prevaleceria a raça inferior. Na esteira dessa teoria, o termo degeneração, de uso corrente entre os naturalistas sem conotação patológica alguma, assumiu nuanças negativas (Facchinetti \& Munoz, 2013).

A publicação do Traité des dégénérescences physiques, intelectuelles et morales de l'espèce humaine et des causes qui produisent ces variétés maladives (Tratado das degenerescências na espécie humana, 1857), de Benedict Augustin Morel (2008) marcou a apropriação pela psiquiatria moderna, através de um dos seu fundadores, da tese que interpreta as degenerescências como degradações da originária natureza humana, desvios transmissíveis que tornariam os indivíduos e seus descendentes incapazes "de cumprir sua função na humanidade" (Morel, 2008 , p. 500). Caberia à higiene social a tarefa de uma profilaxia para impedir a transmissão de taras, vícios e traços físicos e morais degenerados: um dos meios

\footnotetext{
5 Em 1868 tal tese foi explorada no concurso: Questão étnico-antropológica: o cruzamento das raças acarreta a degradação intelectual e moral do produto hibrido resultante? (Moreira, 1868). O proponente é anônimo, mas é noto o nome do avaliador do texto: Nicolau Joaquim Moreira. A tese proposta, de que a mestiçagem melhoraria a raça, não foi aceita pelo avaliador, o qual traz para confirmação de sua posição a respeito das teorias de Gobineau, Cabanis, Couvier e Agassiz.

6 Masiero (2005) aponta haverem quatro posições distintas sobre a questão racial. A $1^{a}$ refere-se a um conceito de raça moldado pela antropologia médica, validada por classificações morfológicas, medidas antropométricas e descrições psicológicas. A $2^{a}$ contempla um conceito de qualidade racial individual independente da origem étnica (exemplo: doentes mentais, portadores de déficit ou doenças seriam nocivos para a qualidade racial). Já a $3^{a}$ diz respeito a um conceito referente a padrões comportamentais, caráter e inteligência que seriam característicos de determinadas raças e eventualmente levariam os indivíduos para a degeneração (alcoolismo, doenças infecciosas). Por fim, a $4^{a}$ apresenta um conceito de raça como aparelho mental autônomo independentemente do biológico. Apesar da variedade de posições, o estigma negativo acerca da constituição mestiça e da presença dos africanos na brasileira permanece, sendo este um evidente resquício da mentalidade escravocrata.
} 
desta profilaxia seria a extinção da raça degenerada7. Desse modo, a questão da constituição de uma população brasileira purificada de suas raízes raciais multifacetadas e devidamente 'higienizada', tornou-se "a principal obsessão dos psiquiatras, como de resto de toda a intelectualidade brasileira do período" (Reis, 2000, p. 135).

A higiene social proposta se baseava numa ciência recém-criada: a eugenia. O termo eugenia remonta ao inglês Francis Galton (1822-1911): este definiu eugenia positiva a parte da ciência eugênica voltada a prever e selecionar os melhores indivíduos dotados biologicamente; e eugenia negativa a parte voltada a eliminar ou controlar a reprodução dos piores (Galton, 1988). Desse modo, Galton acreditava ter descoberto um método racional para intervir no processo da evolução humana e melhorar seu andamento. O pressuposto de Galton era que as raças humanas diferiam em capacidade intelectual, sendo a branca, a mais inteligente; e que, com base nas diferenças entre as raças, seria possível estabelecer uma hierarquia e classificação das mesmas, das supostas mais evoluídas para as mais primitivas ${ }^{8}$ (Masiero, 2005, pp. 199-296; Lynn, 1991, pp. 255-296; Masiero, 2002, pp. 66-79). No Brasil, a eugenia teve grande aceitação entre o final do século XIX e a primeira metade do século XX. Com efeito, dentre os fatores de degradação humana, haveria a mistura entre raças e culturas distantes, incluindo dentre os efeitos a degradação psicológica. O País, por sua história mistura de diferentes raças, foi tomado por eugenistas e evolucionistas sociais como um exemplo de degeneração produzida pela miscigenação racial promíscua (Stepan, 1990) ${ }^{9}$.

Neste contexto, caberia à psicologia e saberes conexos um papel fundamental, quanto à avalição da população e a melhoria da qualidade racial da população. Assim, as categorias psicológicas moldadas nesta perspectiva difundem-se no meio intelectual brasileiro.

Alguns médicos higienistas interessaram-se também pelo fenômeno de Canudos e especialmente pela figura do líder Antônio Conselheiro, dentre eles um importante expoente deste movimento, o médico maranhense Raimundo Nina Rodrigues (1862-1906), professor de Medicina junto à prestigiosa Faculdade de

\footnotetext{
${ }^{7}$ As teorias de Morel introduzidas no Brasil foram contestadas por Silvio Romero, que questionou a existência de uma raça pura e afirmou o caráter definitivo da mescla racial (Skidmore, 1989).

8 Tais referências exploram a fundo os conceitos abordados do autor.

${ }^{9}$ Entre eles, o conde francês J. A. Gobineau, que esteve no Brasil entre abril de 1869 e maio de 1870, como diplomata. Entre o fim do século XIX e as primeiras décadas do século XX se falava em uma suposta "evolução psíquica da raça" (Silva, 1931, pp. 3-4); "psico-eugenia" (Lopes, 1938, pp. 621622), "aperfeiçoamento mental" (Kehl, 1919 e 1929, pp. 219-226), "psicologia do eugênico" e "eugênico psíquico" (Vianna, 1919, pp. 3-4), "psicologia étnica" (Vianna, 1927/1991, pp. 69-73), dentre outros.
} 
Salvador e pioneiro nos campos da etno-psiquiatria e da medicina legal ${ }^{10}$. Nina Rodrigues defendeu a tese de que o Conselheiro sofria de uma patologia mental, classificando-a como delírio crônico de Magnan, diagnóstico embasado em uma teoria que também contemplava a potencial predisposição à loucura, e explicitando as fases da doença em seu artigo A loucura epidêmica de Canudos, publicado na Revista Brasileira em novembro de 1897 (ano II, tomo XII) (Oda, 2000). Para o médico, haveria uma forte correlação entre a propensão a patologias mentais e fatores étnicos e de classe social: atribuíra assim a "loucura religiosa" desenvolvida por Antônio Conselheiro a causas quais: o fato dele ser mestiço, "filho do sertão" e possuidor de uma "religiosidade medieval" (p. 142). Tais elementos fariam com que ele reagisse a fatores externos relevantes - tal como o fim da Monarquiaincorporando-os ao seu delírio (Oda, 2000). Seguindo esse raciocínio acerca da existência de grupos propensos a desenvolver delírios dessa ordem, Rodrigues aplica a sua teoria do contágio da loucura à comunidade canudense, alegando que aquelas pessoas estavam sujeitas a um alto grau de contágio em função da composição étnica da população (majoritariamente composta por negros, mestiços e sertanejos) e da sua organização social primitiva, a qual tornava-os mais vulneráveis. Elas eram consideradas como o elemento passivo desse desvio coletivo (súcubus), contagiados por Antônio Conselheiro, o elemento ativo (íncubo) e detentor da patologia original (Oda, 2000). Posteriormente, ao ter a oportunidade de analisar o crânio de Antônio Conselheiro, Rodrigues buscou pelas evidências fisiológicas de que aquele era um exemplo de degenerescência mental. Contudo, não encontrou as evidências necessárias, concluindo que aquele era um exemplo de delírio crônico de Magnan o qual acometia aos "predispostos simples" devido a sua condição social (Oda, 2000).

O panorama acima traçado permite melhor entender o significado da interpretação fornecida por Euclides da Cunha em seu romance: ele atingiu desses saberes e se fez porta voz deles na descrição de Conselheiro e de seus adeptos. 0 uso de categorias derivadas desses saberes na escrita do texto dos Sertões será evidenciado ao longo do artigo.

\section{O universo sociocultural de Antônio Conselheiro e dos canudenses}

\footnotetext{
10 Skidmore (1989) assinala que Rodrigues foi o primeiro pesquisador a estudar a influência africana de maneira sistemática, realizando cuidadosa catalogação das origens etnográficas africanas dos escravos trazidos no Brasil. No entanto, apesar dele mesmo ser "jovem doutor mulato", Nina Rodrigues foi "o principal doutrinador racista brasileiro da sua época" (Skidmore, 1989, p. 75).
} 
Diferente da visão de mundo de Euclides e dos saberes produzidos por seu universo cultural, o contexto social dos canudenses é composto por diversas referências de matrizes indígenas, jesuítas e africanas/afro-brasileiras. Localizada numa altitude de acerca quatrocentos metros, a Fazenda Canudos se encontra no território entre o vale do Rio Vaza-Barris e o Polígono da Seca, situado entre os Estados de Alagoas, Bahia, Ceará, Minas Gerais, Paraíba, Pernambuco, Piauí, Rio Grande do Norte e Sergipe. O local foi rebatizado de Belo Monte na ocasião da instalação de Antônio Conselheiro e de uma pequena comunidade de acerca de 250 seguidores em 1893. Moravam inicialmente em pequenas casas por volta de uma praça e uma capela. A partir de então a população cresceu vertiginosamente passando a contar 25 mil habitantes em 1897. O povoado desfrutava de posição privilegiada pois por ali passavam vários caminhos abertos à penetração do rio São Francisco. Desse modo, Canudos tornou-se lugar de pouso de viajantes e criadores de gado. Segundo Calasans:

[...] eram os grupos de adeptos que surgiram todos os dias, procedentes de diversos pontos da Bahia e de Sergipe. Vinham, sobretudo, daqueles lugares por onde peregrinara, durante mais de vinte anos, o Santo Conselheiro. Gente do Tucano do Itapicuru, de Entre Rios, de Inhambupe, do Conde, de Pombal, de Monte Santo, de Alagoinhas, de Massacará, de Jeremoabo, de Curaçá, de Campos, de Itabaianinha, de Vila Cristina, do Geru. Pessoas de recursos, que vendiam sua terra e seu gado. Homens e mulheres paupérrimos. Índios do aldeamento de Mirandela e Rodelas, certamente localizados na Rua dos Caboclos; pretos libertados pela Lei Áurea, conhecidos por 13 de maio, que deviam predominar na 'rua dos negros'. Doentes mentais, aleijados, incapacitados que viviam das esmolas do Bom Jesus e esperavam seus milagres. Todos atraídos pelo poder de Antônio Conselheiro, pelos seus conselhos, pelo lenitivo que ele Ihes podia proporcionar (Calasans, 2002, p. 75).

Tratava-se, portanto, de um grupo expressivo de diferentes identidades culturais e sociais presentes naquele território.

Em relação às tradições indígenas, os canudenses carregavam traços das populações tupi-guaranis. Essas ocupavam uma região geograficamente próxima àquela onde se desenvolveu a população originaria de Canudos. Essa nação indígena foi uma das que teve maior contato inicial com os portugueses e com os missionários jesuítas (Campos \& Claro, 2012, p. 231). Visto que os povos nativos possuíam uma cultura oral e não haviam desenvolvido registros escritos, a maneira de conhecer seus comportamentos, hábitos e organização social durante esse período foi através das cartas escritas pelos europeus que vieram ao Brasil (Massimi, 2003). Através desses documentos, tornou-se conhecido que os Tupis- 
Guaranis tinham a tradição de se deslocarem em busca de uma região que acreditavam ser a morada de seus ancestrais e também local de grande abundância, juventude e imortalidade, chamada por eles de "Terra sem mal" (Campos \& Claro, 2012, p. 232). Era comum que profetas indígenas (os feiticeiros) percorressem as aldeias apresentando-se como reencarnações de antepassados lendários e "procurando convencer seus habitantes a abandonar o trabalho e dançar" (Campos \& Claro, 2012, p. 232). De modo geral, essas populações tinham comportamentos nômades ou seminômades, mas através do contato com os portugueses e através da constituição de aldeamentos feita pelos missionários jesuítas, iniciaram um processo de sedentarização, constituindo formas de agregação comunitárias (Couto, 1988). Dentro das sociedades indígenas, além dos feiticeiros, ou pajés, mediadores espirituais da vida da tribo, também era comum haverem lideranças militares, os chefes guerreiros, chamados caciques. Contudo, essas lideranças não possuíam privilégios socioeconômicos por ser a estrutura da vida social indígena essencialmente comunitária, conforme atestam os relatos de missionários e viajantes do século XVI (Massimi, 2003; Campos \& Claro, 2012). Os índios viviam em grandes cabanas chamadas ocas, onde residiam muitos grupos familiares. Não existia a propriedade privada e o trabalho era distribuído igualmente entre os membros da aldeia: os relatos que descrevem o cotidiano da vida nessas comunidades indígenas, relatam que pela madrugada, o cacique, nas ocas, realizava uma pregação e repartia o trabalho (Massimi, 2003). Os saberes psicológicos decorrentes desta visão do mundo possuíam um forte marco comunitário, onde o indivíduo era concebido como parte do todo que era o grupo (Massimi, 2003).

Os missionários da Companhia de Jesus se fizeram presentes nas regiões do sertão baiano a partir de 1667 (Leite, 1938, pp. 282-283). No contexto de seu estilo evangelizador, eles incorporaram várias tradições dos nativos às suas próprias: por exemplo, utilizavam da oratória e da palavra retoricamente ordenada para persuadir e ensinar, algo apreciado pelos Tupi-Guaranis cujos chefes, como vimos, também costumavam discursar às tribos em diversas circunstâncias (Massimi, 2005). As práticas oratórias dos jesuítas e de modo geral dos pregadores católicos baseavam-se nos conhecimentos da arte retórica cuja finalidade era mobilizar as potências anímicas (entendimento, memória e vontade) através da palavra (Massimi, 2003). A pregação era disseminada pelo Brasil, no período colonial, atividade difusa e muito valorizada pela população (Massimi, 2005), especialmente nas regiões Norte e Nordeste. Por exemplo, Salvador se tornou um dos mais importantes centros de difusão dessa oratória sagrada. Mas no sertão nordestino houve também a difusão de pregadores itinerantes, que realizavam 
suas práticas oratórias a fim de reformar os costumes e pacificar as relações sociais dos lugares pelos quais passavam (Massimi, 2005). Os jesuítas traziam e difundiam uma visão do mundo em cujo âmbito também desenvolveram saberes acerca da pessoa e de seus fenômenos psíquicos, saberes esses que foram transmitidos junto às populações onde desenvolviam o trabalho missionário (Massimi, 2003; Massimi, 2020).

Por sua vez, os povos africanos passaram a constituir uma camada expressiva da população local devido ao tráfico de escravos durante o século XVI, compondo e mesclando culturalmente elementos de tradições e práticas que traziam de seus povos ancestrais (Campos \& Claro, 2012). Nesse período, 45\% da população, ou cerca de cinco dos onze milhões de africanos traficados como escravos para as Américas, eram centro-africanos. Um primeiro elemento referente às tradições de matriz africana incorporado no Brasil se refere ao calundu, religião dos povos Bantos (povos da África central) praticado principalmente na Bahia e em Minas Gerais, durante o período colonial (Daibert, 2015). Tais práticas se estruturavam no culto de entidades, tais como: a divindade suprema, os arquipatriarcas, os espíritos da natureza, os ancestrais e os antepassados. De acordo com tal tradição, a vida seria sustentada por um Ser Supremo, o qual reina sobre o universo e sobre os homens de modo distante e benéfico (Daibert, 2015). Isso acarretava um estreito vínculo com a natureza, bem como uma grande relevância e valorização da memória e história e dos antepassados por parte desses povos (Massimi, 2020). Os antepassados e os anciãos eram tidos como depositários da sabedoria advinda de suas tradições. Os africanos da diáspora, apesar de terem sido desenraizados pelo sistema escravocrata, tinham um profundo sentido comunitário: para eles, a existência se tornaria sem sentido sem a interação na comunidade, participando do movimento, relações e conexões proporcionadas por ela (Daibert, 2015). No Brasil, houveram originais formas de acomodação entre praticas católicas e tradições africanas: a adesão maciça dessas populações às Irmandades, associações comunitárias de cunho religioso, difundidas na cristandade da época, especialmente das Irmandades dos Pretos de Nossa Senhora do Rosário (Boschi, 2004). Contudo, a maioria das expressões culturais trazidas pelos povos africanos (tais como práticas de sua religião e língua nativa) costumavam ser duramente reprimidas, uma vez que poderiam se tornar sementes de rebeldia e resistência, sendo permitida a sua existência apenas dentro dos interesses da elite local (Romão, 2018). Desse modo, outra forma encontrada, tanto pelos bantos quanto por outros povos e seus descendentes, de perpetuar as tradições de seus ancestrais foi através do sincretismo religioso, estabelecendo conexões entre as entidades veneradas por eles e figuras da fé católica, sendo o caso de originarem- 
se religiões tipicamente brasileiras, como a umbanda, por configurarem essa mescla entre santos e orixás (Romão, 2018). Outro aspecto relevante da organização social e comunitária do povo preto eram os quilombos. Essa era uma forma de organização comunitária já existente na África composta por um conjunto de aldeias encabeçadas por um líder (rei) pertencente à linhagem chefal, o qual assumia a liderança e possuía obrigações religiosas e cujo poder não era absoluto, mas composto pelos demais chefes de aldeias e linhagens em uma gestão conjunta, cujas tradições eram passadas oralmente (Munanga, 1996). Essa organização foi reproduzida no Brasil pelos escravos que fugiam e construíam condições de autonomia e subsistência a fim de sair do regime escravocrata, tornando-se um símbolo de resistência negra no Brasil e potencial ameaça ao poder das elites regionais (Nascimento, 1980). Nessas vivências coletivas, se enraizava o sentimento de pertencimento ao grupo e à terra, configurando uma expressão de identidade étnica e de territorialidade, como também saberes psicológicos (Schmidt, Turatti, Manzoli \& Carvalho, 2002; Massimi, 2020).

Por fim, cabe lembrar um traço comum ao catolicismo nordestino dos séculos XVII e XVIII: o das missões itinerantes, método de ação catequética destinado a acudir às populações sertanejas, distantes de centros urbanos e, em maioria, caracterizadas por uma cultura oral (Costa \& Silva, 1982). Tais missões eram realizadas por ordens religiosas, dentre as quais se destacaram os capuchinhos, e eram caracterizadas por formas de expressividade dramática que suscitavam fortes emoções. Seus temas principais eram os Novíssimos do homem, a saber, a consideração da morte, o juízo, o inferno e o paraíso; a mística da cruz em cujo horizonte era significada a vivência de sofrimento própria daquelas populações e que se expressava através das procissões do enterro do Senhor morto e os cultos penitenciais tais como a procissão das almas; e o tema da esperança, do advento e do nascimento ligados à chegada da chuva e ao fim da seca (Costa \& Silva, 1982). Tratava-se de práticas rituais e religiosas as quais promoviam modalidades de elaboração da experiência pessoal e comunitária (Massimi, 2005; Massimi, 2020).

Em suma, a população da região de Canudos portava a memória e os traços de diversas tradições culturais presentes no território, evidenciados também nos relatos dos sobreviventes que serão analisados e de que Antônio Conselheiro se fez porta-voz junto deles. No âmbito dessas tradições, havia também o encontro entre diversos saberes psicológicos.

\section{A questão das temporalidades}


Além da comparação entre os dois universos socioculturais do escritor Euclides da Cunha e dos atores do movimento de Canudos, cabe considerar a diferença entre as percepções do tempo (temporalidade) vivenciadas por ambos. No horizonte da história da cultura, o prevalecer das teorias modernas (das quais Euclides se faz porta-voz) sobre o arcabouço dos saberes tradicionais, pode ser interpretado como expressão de uma percepção do tempo que se difunde ao longo do século XIX, e que se distancia da vivência da temporalidade nas culturas tradicionais do Brasil colonial. Especificamente, a análise comparativa entre o texto de Euclides da Cunha e os depoimentos dos sobreviventes de Canudos pode focar os sentidos do tempo explicitados em ambas as fontes.

A temporalidade, na perspectiva sugerida pelo historiador François Hartog (1996), é o sentido do tempo entrelaçado às relações humanas, dando origem a vivências peculiares em diversos períodos históricos e contextos geográficos. Existiriam, portanto, diferenças quanto à experiência do tempo dos indivíduos e das comunidades. Tais vivências diferenciadas são chamadas de Regimes de historicidade. Na história ocidental, haveria, por exemplo, uma vivência do tempo focada na experiência do passado, do qual derivariam critérios para viver o presente e planejar o futuro em sociedades onde a memória e a tradição ocupam lugares de destaque na cultura. Seria o regime de historicidade que Hartog chama de historia magistra e que vigorava no mundo clássico e medieval. $\mathrm{E}$, haveria também uma vivência do tempo onde o futuro é o que norteia as ações do presente, numa perspectiva utópica onde o passado deve ser superado para dar lugar à novidade, ou modernidade. Seria o Regime de historicidade que Hartog define como moderno ${ }^{11}$.

Para o nosso estudo, a questão que podemos propor é se haveria alguma diferença quanto à percepção da temporalidade do escritor Euclides da Cunha e a dos atores dos eventos por ele narrados. Seriam os canudenses ligados a um sentido do tempo próprio das culturas tradicionais do Brasil colonial pautado na memória do passado? Seria outra a perspectiva de Euclides, inspirada nas concepções evolucionistas e positivistas da história e, portanto, voltada ao progresso e ao futuro?

\footnotetext{
${ }^{11}$ Segundo Hartog, existem três principais Regimes de Historicidade: a História Magistra Vitae, o Regime Moderno e o presentismo. O primeiro consiste em uma vivência do tempo considerando as tradições como chave para a construção de futuras experiências. Já a segunda, diz respeito a um modelo que considera o passado como superado, dando lugar a um futuro utópico. Por fim, temos o presentismo que, como sugere o nome, consiste em uma temporalidade em que o presente é o limite de si mesmo: não há passado, ou futuro como critérios ou referenciais de orientação, mas apenas o tempo presente. O passado se torna algo inexistente e o futuro vai perdendo o sentido.
} 
Não será este o foco principal de nossa pesquisa, mas a pergunta norteará como pano de fundo, o percurso que aqui realizaremos, abrindo caminhos para futuras investigações sobre esse tema.

\section{Resultados da análise comparativa dos tópicos levantados}

A seguir são analisados, de maneira comparativa e à luz dos contextos acima descritos, de que forma os tópicos levantados são abordados pela narrativa de Euclides e pelos depoimentos e memorial dos sobreviventes. Busca-se compreender o significado desses tópicos no âmbito dos respectivos universos culturais, focando aspectos relacionados aos conhecimentos das ciências da vida mental e aos saberes psicológicos.

\section{O Misticismo do Antônio Conselheiro}

A dimensão mística do Conselheiro aparece seja nos textos de Euclides seja nos depoimentos, em diferentes aspetos. Em primeiro lugar, quanto à fisionomia.

$\mathrm{Na}$ narrativa de Euclides estes traços adquirem conotação negativa: "... E surgia na Bahia o anacoreta sombrio, cabelos crescidos até os ombros, barba inculta e longa; face escaveirada; olhar fulgurante" (2015, p. 165). Pelo contrário, nos depoimentos dos sobreviventes, os traços fisionómicos de Conselheiro sinalizando sua visa ascética adquirem conotação positiva: "Nunca mais pude esquecer aquela presença. Era forte como um touro, os cabelos negros e lisos Ihe caíam nos ombros, os olhos pareciam encantados, de tanto fogo [...]" (Honório Vilanova. Em: Macedo, 1983, p. 37).

O caráter do Conselheiro sinaliza sua vivência interior. Na escrita de Cunha, a vida interior desse é tomada apenas na dimensão psíquica, não havendo nenhuma referência à dimensão espiritual, e interpretada explicitamente à luz da psicologia social e da psiquiatria da época: "O historiador só pode avaliar a altitude daquele homem, que por si nada valeu, considerando a psicologia da sociedade que o criou. [...]. Pode ser incluído numa modalidade qualquer tipo de psicose progressiva" (2015, p. 152). A dimensão das vivências espirituais (cuja existência peculiar é desconhecida por aquela psicologia) adquire, portanto, o significado de uma patologia mental, na esteira das concepções da psiquiatria de Nina Rodrigues que inspiraram o diagnóstico por ele formulado acerca de Antônio Conselheiro.

A postura de Cunha se inspira nas referências culturais e concepções psicológicas difundidas do mundo acadêmico brasileiro de seu tempo. Em 1874 fora publicado o primeiro livro positivista, o primeiro manifesto do Positivismo 
brasileiro, que é o livro Três Filosofias ${ }^{12}$, do médico e filósofo paulista Luís Pereira Barreto. No texto, é veiculada a definição comtiana de Psicologia tomada como Fisiologia Mental, que permite a localização dessa nova ciência no âmbito dos estudos médicos. Além dele, outros médicos seguem a visão de Auguste Comte. O médico paulista Pedro de Alcântara - por exemplo - afirmava: "Por sua natureza - verdadeira physiologia das funções mentaes - a psychologia experimental ha de encontrar sempre na medicina o ambiente melhor ao seu desenvolvimento" (1924, p. 4). O neuropsiquiatra carioca Nilton Campos refere-se a Comte em uma conferência realizada junto ao Serviço de Neuropsiquiatria da Assistência Municipal do Rio de Janeiro (1935). Medeiros afirma que o objeto investigado pela Psicologia é a "relação inegável que há entre certos estados de consciência, ou melhor de certos phenomenos psychicos, e estados physiologicos" (1908, p. 40). Portanto, o referencial teórico de vários autores parece ser uma visão positivista da ciência. $A$ ciência assim concebida proporcionaria ao homem a possibilidade de "assegurar alguma felicidade no plano da vida terrena" (Campos, 1935, p. 64) permitindo "aplicações práticas úteis ao homem e a sociedade" (Campos, 1935, 63). A matriz positivista faz-se evidente entre outros na recusa da Metafísica e da dimensão transcendente da realidade. A experiência religiosa, portanto, é interpretada em termos puramente psicológicos (tendo em vista uma psicologia pautada apenas na fisiologia). "Não compreendo Psicologia, que não seja experimental", afirma Carlos Ribeiro (1932, p. 327). O conceito de Psicologia como uma ciência que se coloca entre Biologia e Sociologia, a declaração da neutralidade do cientista frente às questões éticas e culturais, são também heranças dessa postura filosófica presentes nos psicólogos brasileiros da época. Afirma Nilton Campos, numa conferência pronunciada, em qualidade de paraninfo, para os estudantes de Enfermagem Social: "O homem de sciencia deve permanecer neutro diante da esphera dos valores. É da própria essência do espírito scientifico ficar indiferente as categorias ethicas" (1935, p. 223). E, nesse sentido, continua: "Em minhas modestas aulas, nunca vos defini o que era a pessoa humana, sob o ponto de vista finalístico de sua significação no plano dos valores morais. Permaneci submisso ao postulado da indiferença que todo cientista puro deve atender dentro do domínio da pesquisa scientifica" (Campos, 1935, p. 224). Assim, apenas na lição final do curso. Nilton Campos lembra aos seus alunos que "o homem é um anjo, é um animal, é um monstro" (1935, p. 224). Em suma, no plano da Psicologia, a postura da neutralidade implica eliminar do domínio científico a discussão acerca da visão de

12 Barreto, L. P. (1874). Tres philosophias, primeira parte: philosophia theologica. Rio de Janeiro: Ed. Laemmert. Barreto, L. P. (1876). Tres philosophies: philosophia metaphisica. Jacarehy: Typ. Commercial, 1876. 
homem, pois isso implicaria - na ótica de Campos - uma volta à Metafísica: "deixou a psychologia de ser metaphysico estudo do psychismo humano, encarando o homem como ser ideal, para tornar-se um instrumento scientifico de analyse concreta da vida psychica do homem, considerado como entidade real psychobiologico na escala dos seres vivos, que se congregam em sociedades nos seus graus de desenvolvimento diverso" (1935, p. 5). Dessa forma, a Psicologia cessa de ser "devaneio literário" torna-se poderoso instrumento de acção scientifica" (Campos, 1935, p. 6), inclusive na avaliação dos fenômenos sociais (Massimi, 2016). Portanto, neste contexto intelectual, podemos melhor entender os rótulos empregados por Euclides da Cunha.

Todavia, para os seguidores de Conselheiro, as características de sua personalidade assumem totalmente outra conotação. Sua "santidade" é evidenciada pelo teor de seus "conselhos" inspirados nos mandamentos bíblicos: "Só podia ser um santo homem. Não mandava matar, não mandava mentir, não mandava furtar. Só levava para o bem" (Velho Mariano. Em: Tavares \& Verger, 1947, p. 52).

Análogas considerações valem para a avaliação dos traços comportamentais de Conselheiro que remetem à sua vivência religiosa. Escreve Euclides: "Todas as crenças ingênuas, do fetichismo bárbaro às aberrações católicas, todas as tendências impulsivas das raças inferiores, livremente exercitadas na indisciplina da vida sertaneja, se condensavam no seu misticismo feroz e extravagante" (2015, p. 153). A referência ao termo "raças inferiores" evidencia a inspiração nas teorias racistas e evolucionistas que acima mencionamos (p. 153). Pelo contrário, os canudenses, atribuem a Conselheiro a capacidade de realizar gestos extraordinários, milagrosos, a partir de sua vida de fé e oração: "Sem levantar os olhos do trabalho, ele respondeu: - Fiquem quietos. Dentro de duas horas os soldados se retiram. -E assim aconteceu" (Honório Vilanova. Em: Macedo, 1983, p. 134).

Em suma, as modalidades opostas de interpretar o misticismo de Conselheiro por parte de seus seguidores e por parte de Euclides evidenciam o confronto entre dois universos culturais quase totalmente estranhos um ao outro, fato este que evidentemente dificultava conhecimento, diálogo e intercâmbio.

\section{Descrição das práticas e comportamentos de Antônio Conselheiro}

Os canudenses se referem ao Antônio Conselheiro como ao "Peregrino", a partir de práticas e condutas por eles observadas e compartilhadas. Euclides narra a adesão dos canudenses a proposta de seu líder em termos de uma peregrinação 
ao mesmo tempo física e ideal "Encalçavam-no na rota desnorteada os primeiros fiéis. [...] Chegaram-lhe espontâneos, felizes por atravessar com ele os mesmos dias de provação e misérias" (2015, p. 167). Para os canudenses, a prática da peregrinação expressa o seguimento concreto do ideal do cristianismo: "Ando neste mundo imitando a Deus Nosso Senhor. Quando ele andava na terra, seguiam-Nas cinco mil pessoas: e as boas andam em companhia das más porque assim ganham a salvação! " (Honório Vilanova. Em: Macedo, 1983, p. 129).

"Andou neste mundo imitando a Deus Nosso Senhor. Quando ele andava na terra, seguiam-nas cinco mil pessoas: e as boas andam em companhia das más porque assim ganham a salvação! "; "Ele (peregrino) caminhava, nesse tempo, pelo sertão da Bahia, na pregação da palavra de Deus. Entrava nas cidades para ensinar as orações ao povo e o povo caminhava com ele e com ele trabalhava de graça muitos dias, carregando pedra, tijolo e madeira para os oratórios, igrejas e cemitérios" (Cunha, 2015, p. 176)

A associação entre peregrinação e conversão cristã/salvação é uma tópica da tradição cultural do catolicismo, particularmente acentuada na Idade moderna e presente na cultura brasileira daquele período. Na perspectiva da história dos saberes psicológicos, essa tópica se refere à dimensão histórica e dinâmica da existência humana tida como um percurso tendo origem e destino ${ }^{13}$. A figura de Antônio Conselheiro parece evocar "a figura do homo viator, peregrino, romeiro e o viajante, sempre presentes (...) na cultura brasileira a partir da fé católica" (Santos. Em: Massimi, 2012, p. 283). Esse tema e essa prática parecem agregar as diversas tradições culturais que vimos presentes na comunidade de Canudos: por um lado, a peregrinação em busca de uma "Terra sem males" característica do "modo de ser" dos índios guaranis (Eliade, 1991; Melià, 1990, p. 41); por outro, a tradição dos missionários da Companhia de Jesus, presentes no sertão brasileiro, que transmitiam a memória da peregrinação em Jerusalém, muito cara ao fundador, Inácio de Loyola ${ }^{14}$. O nordeste brasileiro, notadamente a Bahia, foi também o lugar onde ocorreu a escrita, a circulação e a transmissão (lida ou oral) de duas importantes novelas da cultura brasileira as quais têm por tema a figura do peregrino: História do predestinado Peregrino e de deu irmão Precito (1682) do jesuíta Alexandre de Gusmão; e o Compêndio narrativo do peregrino de América

\footnotetext{
${ }^{13}$ A peregrinação possui origens muito antigas, em diversas culturas e contextos geográficos do Oriente e do Ocidente, além de viagem na qual há a busca pela pátria perdida estar presente em diversas representações literárias em todos os tempos. Ao empreender o caminho, o peregrino sempre carrega em si uma espera, um pedido, uma exigência: a realização de um desejo; encontrar o sentido de sua vida; a cura de uma doença, etc. (Oursel, 1979).

${ }^{14}$ Ele próprio destaca em sua autobiografia: "pensava em ir a Jerusalém descalço" (Loyola, $1555 / 1991$, p. 23).
} 
(1728) de Nuno Marques Pereira ${ }^{15}$. A segunda foi lida e citada em sermões pelo próprio Antônio Conselheiro (Vasconcellos, 2017).

No Compêndio, a figura alegórica do interlocutor do Peregrino, o Ancião (que representa o Tempo), parece ter inspirado Conselheiro no que diz respeito ao traje e á postura. O Ancião desempenha a função de um diretor espiritual, aquele que já peregrinou e completou seu trajeto; e é assim descrito: "Vinha ele vestido á cortezã; barba crescida, e muito branca; cabelos próprios até os ombros; com um báculo na mão; e no alto dele um relógio do Sol, e outro de horas, que em um cordel o prendia, e lhe servia de prumo, quando dele usava" (Pereira, 1728/1939, p. 20). Descrição que mantém semelhanças com os retratos verbais acerca de Antônio Conselheiro que acima foram citados. Mas sobretudo são indícios da inspiração recebida pela leitura da novela, os trechos dela que Conselheiro cita em seus sermões (Vasconcellos, 2017). E é justamente a ênfase na observância dos dez Mandamentos como percurso certo do caminho humano rumo ao seu Destino, o tema que aproxima a novela à pregação e aos escritos de Conselheiro. Na perspectiva e ambos, os mandamentos são leis decorrentes da própria natureza do homem criada por Deus. Um dos escritos de Conselheiro, "Como Adão e Eva foram feitos por Deus. O que sucedeu no Paraíso até que foram desterrados dele por causa do pecado" reproduz de modo quase literal o capitulo oitavo do Compendio de Nuno Marques Pereira (p. 95): nesse capítulo, Peregrino, ao discorrer ainda sobre a criação do primeiro homem, Adão, afirma ser este feito a imagem e semelhança de Deus e composto também de quatro humores, referentes aos quatro elementos - terra, água, ar e fogo - "dando a Terra a matéria de que foi criado; a Água, para a composição da massa; o Ar, o refrigério para respirar; o Fogo, para o calor natural" (Pereira, 1939, p. 95, vol. I).

Os estudos na área da história dos saberes psicológicos desenvolvidos acerca das duas novelas apontam para a importância da tópica da peregrinação no que diz respeito à concepção do dinamismo psíquico, de suas desordens e de sua ordenação (Massimi, 2012). Reconhecer-se a si mesmo enquanto peregrino implica, portanto, um certo tipo de elaboração da experiencia psicológica que possivelmente fora vivenciado também por Conselheiro e seus seguidores. Com efeito, recentes estudos acerca do valor pedagógico das práticas da peregrinação assinalam que elas proporcionam a ortopraxi: trata-se da construção de uma vivência disciplinada. Esta permite que o usuário/praticante identifique a si mesmo

\footnotetext{
15 A novela alegórica do jesuíta baiano, Alexandre de Gusmão A História do Predestinado Peregrino e seu Irmão Precito (1682), narra a peregrinação dos dois personagens principais em busca da cidade onde estabelecer definitivamente sua morada: para um será Jerusalém, para outro, Babilônia. Já o Compêndio Narrativo do Peregrino da América foi, ao longo do século XVIII um livro de grande circulação, tendo várias reimpressões por ser uma obra bem aceita durante o período colonial.
} 
ao longo de um percurso que envolve uma dimensão temporal e também um deslocamento espacial visando favorecer uma ensimesmarão com modelos exemplares (Carruthers, 2016). No caso de Canudos, isto significava ensimesmar com a figura de Conselheiro e aderir aos valores religiosos e morais que ele ensinava.

Outras práticas religiosas realizadas em Canudos são de tipo penitencial. Assim as descreve Euclides, referindo-se a Conselheiro: "Vivia de esmolas, das quais recusava qualquer excesso, pedindo apenas o sustento de cada dia. Procurava aos poucos solitários. Não aceitava leito algum, além de uma tábua nua e, na falta desta, o chão duro" (2015, p. 167). E os sobreviventes lembram que "a sua palavra era ouro de lei. A sua mão, suave. O bastão era apenas para apoiar o corpo moído de tantos sacrifícios e rezas" (Honório Vilanova. Em: Macedo, 1983, p. 67).

A prática da penitência foi introduzida no Brasil pelos missionários e era utilizada com uma função ordenadora da vida psíquica e espiritual dos fiéis, podendo ser articulada juntamente ao exame de consciência, com o ato religioso da confissão dos próprios pecados. Portanto, a penitência era realizada não apenas como expressão de arrependimento, mas como uma educação ao equilíbrio entre as virtudes e a ordenação dos sentidos e dos afetos (Massimi, 2012).

Na tradição do catolicismo, o processo de formação da experiência cristã era chamado também de medicina da alma, considerada como o conhecimento do ser humano e da sua dinâmica psicológica, tendo em vista a mudança de costumes e de crenças, de modo a alcançar a virtude e o bom regime de vida (Massimi, 2005). A figura do Conselheiro se aproxima à do médico espiritual, descrito também na já citada novela de Alexandre de Gusmão, de matriz inaciana ${ }^{16}$. A ordenação da vida pessoal e social sempre pressupõe a presença ativa desse médico espiritual ${ }^{17}$. O apelido, a conduta, os gestos e as funções desempenhadas por Conselheiro junto

\footnotetext{
16 Impossibilitado de corrigir por conta própria todas as faltas e imperfeições da conduta, Predestinado é encomendado a "um médico muito experimentado e perito nos ataques do espírito a quem chamam Padre Espiritual, para que tivesse cuidado de the aplicar os frutos, folhas, flores conforme pedisse sua necessidade". Gusmão comenta que esse "médico" era tão apreciado que nele depositava-se "todo o feliz sucesso dos Peregrinos que moravam neste bairro, isto é, todo o aproveitamento dos principiantes na vida espiritual" (Gusmão, 1685, p, 265).

17 Segundo a literatura jesuítica, a medicina da alma trata-se de um conhecimento do ser humano e de sua dinâmica psicológica visando à adaptação deste ao contexto social de inserção (a comunidade religiosa e o ambiente em que esta desenvolve sua missão no mundo). Na novela de Gusmão, a desordem da experiência humana é a "doença" que a formação jesuítica, proposta por Inácio e por seus seguidores, busca "remediar". A causa da desordem não é o exercício da vontade em si, mas sim a vontade mal direcionada, insubmissa à razão, sem a qual regride ao nível das paixões, dos apetites sensitivos (Massimi, 2005).
} 
à comunidade ecoavam aspectos dessa figura da tradição cristã, especialmente do catolicismo pós tridentino, conhecida e compartilhada pelos seus seguidores.

Nesse contexto, deve ser compreendido também o sentido de outra prática desenvolvida na sociedade canudense: a reconstrução de igrejas e cemitérios. Narra Cunha: "Reconstruíam-se templos abatidos, renovavam-se cemitérios em abandono; erigiam-se construções novas e elegantes. Os pedreiros e carpinteiros trabalhavam de graça; os abastados forneciam, grátis, indispensáveis; o povo carregava pedras $[\ldots] "(2015$, p. 176). Os sobreviventes lembram que "ele (Conselheiro, ndr) caminhava, nesse tempo, pelo sertão da Bahia, na pregação da palavra de Deus. Entrava nas cidades para ensinar as orações ao povo e o povo caminhava com ele e com ele trabalhava de graça muitos dias, carregando pedra, tijolo e madeira para os oratórios, igrejas e cemitérios" (Honório Vilanova. Em: Macedo, 1983, p. 121). Trata-se de um hábito comum a algumas tradições do catolicismo, especialmente a tradição franciscana, difundida no nordeste brasileiro através dos missionários itinerantes desta família religiosa e que de alguma forma também parece ter inspirado Conselheiro (Sangenis, 2018; Iglesias, 2011; Ilha, 1975). Narra-se que o jovem Francisco, no início de sua busca espiritual, saíra um dia para meditar nos campos e passou perto da Igreja de São Damião, que estava em ruinas. Movido por um impulso espiritual, entrou no templo para rezar e diante da imagem do Crucificado ouviu uma voz que Ihe pedira por três vezes: "Francisco vai reparar a minha igreja que está toda em ruinas". E assim ele fez com a ajuda de alguns amigos (Vita di S. Francesco 1411. Em: Desbonnets, 1974, pp. 38-144). Dali em diante, os franciscanos e os movimentos religiosos inspirados no Santo de Assis, dedicaram-se às atividades de reconstrução de templos religioso em ruinas.

Em suma, a figura de Antônio Conselheiro parece encarnar uma longa tradição religiosa que encontra seu sentido na história da cristianização daquela região do sertão brasileiro. A linguagem e os gestos dele eram, portanto, totalmente compreensíveis para aqueles sujeitos que aderiram ao movimento de Canudos, pois carregavam significados e valores compartilhados e herdados de seus antepassados. Tais significados e valores moldavam inclusive seus modos de ser pessoas, seus dinamismos psíquicos e suas relações sociais. Todavia, essas práticas já não pertenciam mais ao mundo de Euclides e dos intelectuais brasileiros: estes acreditavam que o País se tornaria uma nação moderna somente se rechaçar o passado colonial e suas matrizes católicas.

\section{Descrição da Terra e seus recursos}


A leitura das fontes escolhidas evidencia que o território ocupado pelos canudenses era menos afligido pela seca do que outras regiões do sertão. Neste aspecto, as descrições de Euclides e os relatos/memórias dos sobreviventes parecem convergir.

Escreve Euclides: "Recortam-na pequenos cursos d'água resistentes às secas. Pelas baixadas, para onde descaem os morros, notam-se rudimentos de florestas transmudando-se as caatingas em cerradões virentes" (2015, p. 248). O que é confirmado pelos depoimentos dos sobreviventes: "Legumes em abundância e chuvas a vontade " (Maria Guilhermina de Jesus. Em: Tavares \& Verger, 1947, p. 42). É registrado também um crescimento da população. Segundo Cunha, "Data daquele ano (1893) a sua revivescência e crescimento rápido" (2015, p. 185). Este crescimento é expresso pelos canudenes em termos de força: "Canudos tornou-se forte" (Manoel Ciriaco. Em: Tavares \& Verger, 1947, p. 36).

A disponibilidade de recursos sinaliza a possibilidade da fartura e da superação da fome condição endêmica do sertão. Cunha retrata esta fartura descrevendo em detalhes os alimentos observados no arraial: "Ali estavam carnes secas ao Sol; cuias cheias de paçoca, a farinha de encalço do sertanejo; aiós repletos de ouricuris saborosos. A um canto os bogós transudantes, túmidos de água cristalina e fresca" (2015, p. 325). E os depoentes testemunham: "Havia de tudo, por esses arredores. Dava de tudo, e até cana de açúcar de se descascar com a unha, nascia bonitona por esses altos" (Maria Guilhermina de Jesus. Em: Tavares \& Verger, 1947, p. 42). E ainda: "Quem tinha roça tratava de roça, na beira do rio. Quem tinha gado, tratava de gado. Quem tinha mulher e filhos tratava da mulher e dos filhos. Quem gostava de reza, ia rezar. De tudo se tratava porque a nenhum pertencia e era de todos, pequenos e grandes, na regra ensinada pelo Peregrino" (Honório Vilanova. Em: Macedo, 1983, p. 67).

A importância da busca por uma terra farta como contexto propiciador para a construção de relações sociais positivas, que esses relatos evidenciam, ecoa traços característicos da a tradição dos índios guaranis, que como vimos também tinham morado na região de Canudos. Escreve o antropólogo Bartolomeu Melià:

Os Guarani chegaram a ocupar as melhores terras ( $\ldots)$ especialmente aptas para o cultivo do milho, da mandioca, de vários tipos de feijão, abóbora, batata e amendoim. São terras nas quais a técnica agrícola de roçado permite uma produção altamente satisfatória. A arqueologia os mostra como aldeões horticultores, e as grandes panelas nas quais era preparada a chicha fazem pensar em grandes concentrações festivas e convites recíprocos(...) A vida guarani nunca se liberta, nem se abstrai da questão da terra (Melià, 1990. p. 35). 
A relação positiva com a terra possibilita "um modo de ser bom que se vive plenamente na festa religiosa e no convite comunitário" (Melià, 1990, p. 42). Desse modo, o valor da terra produtiva e das boas relações sociais nela constituídas, reconhecido pelos canudenses, remete a fatores constitutivos da identidade daquela comunidade, notadamente às suas raízes indígenas.

\section{Descrição da população de Canudos e de suas relações com Conselheiro}

A coragem bélica dos canudenses transparece na escrita de Euclides e nos depoimentos. Narra Euclides: "Felizmente os expedicionários [...] tinham prontas as armas para a réplica [...]. Mas os jagunços não recuaram" (2015, p. 269) E afirmam os sobreviventes que os militares "enfrentavam os jagunços, que lutavam com destemor" (Manoel Ciriaco. Em: Tavares \& Verger, 1947, p. 36).

A caracterização da população aparece como totalmente destoante no retrato de Euclides e no Memorial de Vilanova. Escreve o primeiro: "a população constituída dos mais díspares elementos, do crente fervoroso abdicando de si todas as comodidades da vida noutras paragens, ao bandido solto que lá chegava de clavinote ao ombro em busca de novo campo de façanhas, se fez comunidade homogênea e uniforme, massa inconsciente e bruta " (2015, p. 192). Euclides tacha como massa a diversidade de composição social do grupo. O termo massa é rotulo comum à psicologia social e sociologia da época, identificando um tipo de relação social que une as pessoas a partir de uma sintonia de reações afetivas e instintivas, contraposto à comunidade onde as pessoas interagem a partir de uma comunhão de afetos e sentimentos, mas também de concepções e de valores morais (Stein, 1999). E, de fato, esta qualidade de relação social é retratada do Memorial de Vilanova: tratava-se de "gente, zelosa e ordeira nos seus bons costumes, onde não havia uma só mulher prostituta. Do balcão eu via em derredor a quietude e a paz em que findavam os dias" (Honório Vilanova. Em: Macedo, 1983, p. 67).

Quanto ao líder, o apelido de Conselheiro revela a principal forma de relacionamento por ele estabelecido com a comunidade: conforme relata um depoimento de sobrevivente: "Santos e justos eram os seus conselhos a todos, homens e mulheres" (Honório Vilanova. Em: Macedo, 1983, p. 40). O líder desenvolvia uma atividade de aconselhamento das pessoas, sendo seus conselhos reconhecidos como razoáveis ("santos e justos") a partir de critérios de avaliação compartilhados e como já dissemos oriundos de uma tradição cultural e religiosa que acomunava os seus seguidores. De modo análogo afirma Vilanova em suas 
memórias: "Era manso de palavra e bom de coração. Só aconselhava para o bem. Nunca pensei, eu e compadre Antônio, que um dia nossos destinos se cruzariam com o desse homem" (Honório Vilanova. Em: Macedo, 1983, p. 37). A interpretação dada por Euclides da Cunha contrasta com aquelas afirmações: "Não aconselha e consola, aterra e amaldiçoa; não ora, esbraveja. É brutal e traiçoeiro. Surge das dobras do hábito escuro como da sombra de uma emboscada armada à credulidade incondicional dos que o escutam" (2015, p. 151). Inclusive, Euclides faz uma referência a alguns conteúdos destes conselhos contrastantes com a moral higienista: "Porque o dominador, se não estimulava, tolerava o amor livre. Nos conselhos diários não cogitava da vida conjugal traçando normas aos casais ingênuos" (2015, p. 194) e ainda: "Esboça uma moral que é a tradução justalinear da de Montano: a castidade exagerada ao máximo horror pela mulher, contrastando com a licença absoluta para o amor livre, atingindo à quase extinção do casamento" (2015, p. 173). Estas afirmações são desmentidas pelos sobreviventes: "[...] combateu o roubo, a mentira, o homicídio, impediu que vivessem juntos os casais não casados na Igreja. Mandava chamar um padre para batizar, casar, confessar a gente do arraial. Mentira que ele fosse tolerante com o amor livre. Jamais empunhou um fuzil ou um revólver, por acesa que a luta estivesse" (Manoel Ciriaco. Em: Carneiro, 1953, p. 12). E ainda: "Era homem bom e respeitador. Mulher para ele era para se respeitar e muito" (Manoel Ciriaco. Em: Tavares \& Verger, 1947, p. 36). Euclides também atribui à Conselheiro a imposição de hábitos religiosos ao grupo: "Na cadeia ali paradoxalmente instituída [...] viamse [...] presos que haviam cometido a leve falta de alguns homicídios os que haviam perpetrado o crime abominável de faltar às rezas" (2015, p. 195). Mas as falas dos sobreviventes desmentem novamente essas afirmações: "Os homens, repito, não eram tanto de frequentar os ofícios (missa). As mulheres, sim, iam quase todas ao santuário ou à latada, onde rezavam e ouviam pregação" (Honório Vilanova. Em: Macedo, 1983, p. 39).

No que diz respeito às relações sociais emergentes no arraial, destaca-se a cooperação. Relatam os depoimentos: "Quem tinha roça tratava de roça, na beira do rio. Quem tinha gado, tratava de gado. Quem tinha mulher e filhos tratava da mulher e dos filhos. Quem gostava de reza, ia rezar. De tudo se tratava porque a nenhum pertencia e era de todos, pequenos e grandes, na regra ensinada pelo Peregrino" (Honório Vilanova. Em: Macedo, 1983, p. 67) " - "Quem não ajudava? " (Velho Mariano. Em: Tavares \& Verger, 1947, p. 52). Este tipo de relação, de natureza comunitária, é tachado por Euclides como coletivismo tribal: "Por isto a propriedade tornou-se-lhes uma forma exagerada do coletivismo tribal dos beduínos" (2015, p. 193) ". O certo é que abria aos desaventurados os celeiros 
fartos pelas esmolas e produtos do trabalho comum" (2015, p. 199).

Mais uma vez, evidencia-se a incongruência entre a descrição da vida social do grupo e das suas relações com seu líder carismático fornecida pelos sobreviventes e a retratada por Euclides da Cunha. Esta incongruência é expressa inclusive pela diferente terminologia usada para referir-se ao fenômeno comunitário e ao líder: o "ser-de-todos" e a ajuda mutua são chamados por Euclides de "coletivismo tribal"; o "conselheiro" é, aos olhos de Euclides, um "dominador".

\section{Discussão dos resultados}

Os tópicos levantados e comparados entre si evidenciam as diferenças profundas entre a visão de homem e de mundo de Euclides da Cunha e de Conselheiro e seus seguidores. Através dos trechos evidenciados em Os Sertões, vimos que, ao observar condutas alheias ao próprio mundo-da-vida, o escritor interpreta esta alteridade através do emprego de categorias derivadas da psicologia, da psiquiatria e das ciências sociais da época. Determinismo ambiental e determinismo genético fundamentam a intepretação do fenômeno de Canudos. Euclides explicita sua crença nos saberes científicos da época em um dos trechos da obra: "O historiador só pode avaliar a altitude daquele homem que por si nada valeu, considerando a psicologia da sociedade que o criou. [...]. Pode ser incluído em uma modalidade qualquer de psicose progressiva" (2015, p. 152). A assimilação das teorias raciais da época e o estigma da mestiçagem que acima foram descritas transparece em vários trechos de Os Sertões: "A mistura de raças mui diversas é, na maioria dos casos, prejudicial. Ante conclusões do evolucionismo, ainda quando reaja sobre o produto o influxo de uma raça superior, despontam vivíssimos estigmas da inferior. A mestiçagem extremada é um retrocesso" (Cunha, 2015, p. 113). Toda a elaboração da argumentação já toma por base a inferioridade racial de negros, indígenas e mestiços de qualquer gênero, argumentando a respeito da degenerescência dos canudenses ser devido a tal propensão étnica, como pode ser percebido no trecho: "De sorte que o mestiço traço de união entre as raças, breve existência individual em que se comprimem esforços seculares- é, quase sempre, um desequilibrado" (p. 113). As tradições religiosas de matriz indígenas e africana são rotuladas como "fetichismo bárbaro" e as tradições do catolicismo como "aberrações católicas": "Todas as crenças ingênuas, do fetichismo bárbaro às aberrações católicas, todas as tendências impulsivas das raças inferiores [...]" (2015, p. 153). Dentro da perspectiva estabelecida pela adesão ao modelo linear e evolutivo de progresso sugerido pela 
filosofia positivista da história, Canudos seria um caso de selvageria e retrocesso; suas tradições se prenderiam a um passado retrógrado a ser rechaçado, para possibilitar a evolução daquela região e suas populações em direção ao futuro com um sistema de governo superior (República), um novo modelo de urbanização e a disponibilidade de maiores recursos tecnológicos. Todos os elementos culturais e religiosos que remetem às tradições, ao passado daquelas populações são assim estigmatizadas como evidências de um processo de degenerescência, já que na visão positivista comtiana os conhecimentos míticos, religiosos e metafísicos são aspectos primitivos do conhecimento humano, que devem ser superados pela ciência. Em suma, Euclides da Cunha interpreta o fenômeno de Canudos, com base na sua visão de mundo e nas teorias da psicologia, psiquiatria e antropologia cientifica por ele seguidas. A experiência diretamente vivenciada pelo autor no confronto com aquelas populações não é suficiente para questionar suas conviç̧ões teóricas, inclusive pelo fato de que a epistemologia positivista pregava um rigoroso distanciamento entre observador e objeto observado e rechaçava a empatia como ruído e obstáculo ao estabelecimento de uma condição de conhecimento autenticamente cientifica. A confiança no método cientifico como única forma de conhecimento do mundo impedia-lhe de ter uma abertura intelectual para outros saberes e para outros modos de conhecer.

Todavia, valores e práticas da comunidade de Canudos evidenciadas nos depoimentos, adquirem sentido e razoabilidade se forem tomadas na perspectiva de suas raízes históricas e se forem analisadas à luz da história cultural e especialmente à luz da história dos saberes psicológicos. Os modos de ser pessoa e de elaborar a própria experiência psicológica e construir o sentido da própria identidade psicossocial são profundamente enxertados naquelas raízes. Trata-se de raízes que afundam na terra do passado e que constituem a identidade do presente. Ao longo deste artigo demonstrou-se que a dimensão do misticismo ligada à pessoa de Conselheiro e retratada pelos sobreviventes, remete às figuras de pregadores e santidades que permeavam o imaginário e a história cultural daquelas populações. A descrição de Conselheiro, retratado como presença marcante ("nunca mais pude esquecer aquela presença"), pela sua imponência física ("Era forte como um touro, os cabelos negros e lisos lhe caíam nos ombros, os olhos pareciam encantados, de tanto fogo"), e pelos sinais de sua força espiritual ("só podia ser um santo homem. Só levava para o bem"; "A sua palavra era ouro de lei. A sua mão, suave" etc.) assemelhava-se às figuras dos missionários pregadores que percorreram o território brasileiro ao longo do período colonial. O próprio apelido de 'Conselheiro' dado a Antônio Vicente Mendes Maciel, como alguém que "aconselhava para o bem", aproxima sua figura àquela dos 
missionários e pregadores itinerantes que perambulavam pelo sertão ${ }^{18}$. Análogas considerações dizem respeito ao fato de que os relatos dos sobreviventes de Canudos ao descrever a terra e seus recursos e as relações sociais na comunidade, apontam para a fartura da terra e a positividade das relações sociais: o fato de ter "legumes em abundância e chuvas a vontade" (p. 185) e de conviver com "gente, zelosa e ordeira nos seus bons costumes" (p. 67) de modo que "na quietude e na paz findavam os dias" (p. 67), apresentam-se como motivações adequadas para sustentar a razoabilidade da adesão àquela comunidade. As vivências que os canudenses sobreviventes relatam fazem parte de uma longa tradição cuja memória viva se transmite através das gerações e torna profundamente razoável a estima, a adesão e o seguimento, pelos efeitos benéficos verificados nas comunidades e condensados nas suas narrativas. Esses comportamentos de adesão e seguimento tinham motivos adequados, reconhecidos e socialmente compartilhados. Em suma, naquela comunidade, todos os elementos advindos das diversas tradições próprias das diversas componente de seus membros eram atualizadas num modus vivendi peculiar que lhes correspondiam e que de toda forma buscavam preservar e defender. Se for olhada na perspectiva dos regimes de historicidade sugerida pelo historiador francês François Hartog, a comunidade de Canudos era um sujeito social, religioso e político que vivenciava um sentido de temporalidade onde o passado e a tradição, eram os pontos de referência para enfrentar o presente e planejar o futuro (Hartog, 2003). A espessura de suas vivências advinha de camadas de tradições culturais enraizadas na história do território, as quais, sedimentadas e atualizadas numa experiência comunitária, conferiam significado a gestos, ações, posicionamentos.

\section{Conclusão}

A análise comparativa entre os depoimentos dos sobreviventes de Canudos e a narrativa de Euclides da Cunha evidencia o embate entre dois mundos. Conceitos e métodos oriundos das modernas ciências da mente empregados pelo escritor se demonstram totalmente alheios quanto à compreensão de saberes psicológicos,

\footnotetext{
18 Um dos inúmeros exemplos da presença dessas figuras encontra-se na crônica beneditina do Dietário e se refere à atuação do famoso pregador pernambucano Frei Ruperto de Jesus e aos efeitos milagrosos da palavra por ele pregada, capaz de constituir-se em remédio do corpo e da alma. Estando frei Ruperto em Recife, "vendo esta cidade infestada com uma doença (...), subindo ao púlpito declamou com tanto espírito e fervor que em breves tempos se viu extinta aquela peste de entre as criaturas" (Dietário, p. 61). Outro exemplo é a atuação de Frei Plácido de Santa Anna, cujas presença e palavras orientavam seus ouvintes à pacificação das relações sociais, nas áreas urbanas e no sertão: ele "suavemente movia aos ouvintes para as reformas de suas vidas (...). Reconciliava inimigos, compunha discórdias" (Dietário, p. 128).
} 
advindos de visões de mundo presentes na tradição cultural brasileira do período colonial. A profunda descontinuidade que se criara no século XIX entre as ciências psicológicas e sociais contemporâneos e os saberes do passado, em virtude das rupturas produzida pela epistemologia positivista dominante o cenário intelectual brasileiro (Massimi, 2020), evidencia-se aqui nas perspectivas interpretativas conflitantes diante desse evento da história do País e dos anseios culturais e sociais que o fomentaram.

Além do mais, os Canudenses e Euclides da Cunha parecem encarnar diferentes vivências da temporalidade: uma comunidade, aquela de Canudos, onde transparecia a referência ao passado, à tradição para significar valores e práticas do presente; e um intelectual, Euclides da Cunha, voltado para o tempo da modernidade, pautado na realização do projeto da nação-Brasil inspirado numa visão do mundo onde vigoravam as ideias positivistas de ordem e progresso.

\section{Referências}

Alcântara, P. (1924). Da Psychologia Experimental. Revista de Medicina, 6(32-33), $1-4$.

Augusto, C. B. \& Ortega, F. (2011). Nina Rodrigues e a Patologização do Crime no Brasil. Revista Direito GV, 7(1), 221-236.

Barreto, L. P. (1874). Tres philosophias, primeira parte: philosophia teológica. Rio de Janeiro: Laemmert.

Barreto, L. P. (1876). Tres philosophies: philosophia metaphisica. Jacarehy: Typpographia Commercial.

Barreto, L. P. (1967). As Três Filosofias e outras obras filosóficas, 1874. São Paulo: Editora da Universidade de São Paulo-Grijalbo.

Bolsanello, M. A. (1996). Darwinismo social, eugenia e racismo "científico": sua repercussão na sociedade e educação brasileiras. Educar, 12, 153-165.

Boschi, Caio C. (2006). Espaços de sociabilidade na América Portuguesa e historiografia brasileira contemporânea. Varia Historia, 22(36), 291313. https://doi.org/10.1590/S0104-87752006000200004

Bulferetti, L. (1975). Cesare Lombroso: con 20 tavole fuori testo. Torino: Unione Tipografico / Editrice Torinese.

Calasans, J. (2002). Canudos: origem e desenvolvimento de um arraial messiânico. Revista USP, 54, 72-81. 
Campos, N. (1935). Aspectos da Psicologia. Boletim da Assistência Municipal, 223226.

Campos, N. (1935). Os fundamentos positivos da Psicologia moderna. Boletim da Secretaria Geral de Saúde e Assistência, 1(3), 5-10.

Campos, N. (1937). As acquisições da moderna Psychologia. Boletim da Secretaria Geral de Saúde e Assistência, 3(6), 63-67.

Campos. F. \& Claro, R. (2012). Oficina de História. São Paulo: Leya.

Carruthers, M. (2006). Machina memorialis. Meditazione, retórica e costruzione delle immagini (400-1200) (L. Iseppi, Trad.). Pisa: Edizioni della Scuola Normale. (Original publicado em 1998).

Carvalho, J. M. (1987). Os Bestializados: o Rio de Janeiro e a República que não foi. São Paulo: Companhia das Letras.

Costa, J. F. (1979). Ordem Médica e Norma Familiar. São Paulo: Graal.

Costa e Silva, C. (1982). Roteiro da vida e da morte: um estudo do catolicismo no sertão da Bahia. São Paulo: Ática.

Couto, J. (1988). A Construção do Brasil. Lisboa: Cosmos.

Cunha, E. (1884). Ondas e outros poemas Esparsos. Em: E. Cunha. Obras Completas (p. 637). Rio de Janeiro: Aguilar.

Cunha, E. (1966). Em Viagem. Em: E. Cunha. Obras Completas (p. 517). Rio de Janeiro: Aguilar.

Cunha, E. (2015). Os sertões. 14ª ed. Rio de Janeiro: Record.

Daibert, R. (2015). A religião dos bantos: novas leituras sobre o calundu no Brasil colonial. Estudos Históricos, 28(55), 7-25.

Desbonnets, T. (1974). Dalla vita di San Francesco. Leggenda dei tre compagni 1411. Em T. Desbonnets (Cur.). Atas Franciscanae Historiae, LXVII (p. 144).

Eliade, M. (1991). Paradiso e utopia: Il messianismo nella società americana. I Quaderni di Avallon. Rivista di studi sull'uomo e sul sacro, 24, 29-50.

Facchinetti, C. \& Munoz, P. F. N. (2013). Emil Kraepelin na ciência psiquiátrica do Rio de Janeiro, 1903-1933. História, Ciências, Saúde - Manguinhos, 20(1), 239-262. 
Fontes franciscanas dalla vita di San Francesco (1974). Leggenda dei tre compagni 1411. Em T. Desbonnets (Cur.). Atas Franciscanae Historiae, LXVII (p. 144). Edition critique, in AFH, LXVII, pp. 38 -144.

Galton, F. (1988). Natural abilities and the comparative worth of races. Em L. T. Benjamin Jr. (Org). A History of Psychology: original sources and contemporary research (sem pp.). Nova York: McGraw Hill.

Gobineau, A. (1933). Essai sur l'inégalité des races humaines. Paris: Firmin-Didot. (Original datado de 1858).

Gusmão, A. S. I. (1685). História do Predestinado Peregrino e de seu Irmão Precito. Lisboa: Deslandes.

Hartog, F. (1996). Regime de historicidade, tempo, história e a escrita da História: a ordem do tempo. KVHAA Konferenser, 37, 95-113.

Iglesias, T. C. (2011) Fontes franciscanas: os franciscanos na historiografia do Brasil e na história da educação brasileira. Revista HISTEDBR On-line, 11(43), 254-267.

Ilha, Fr. M. (1975). Narrativa da custódia de Santo Antônio do Brasil: 1584-1621. Rio de Janeiro: Vozes.

Kehl, R. F. (1919). O que é eugenia. Em Sociedade Eugênica de São Paulo. Annaes de Eugenia (pp. 219-223). São Paulo: Revista do Brasil.

Kehl, R. F. (1929). Hereditariedade e intelligencia. Boletim de Eugenia, 6(8), 1-4.

Leite, S. (1938). História da Companhia de Jesus no Brasil. São Paulo. Editora Loyola.

Lopes, E. (1938). Eugenia e hygiene mental [conferência na Sociedade de Medicina e Cirurgia de São Paulo - Sessão 10/outubro/1938]. Annaes Paulistas de Medicina e Cirurgia, 6, 621-622.

Loyola, I. (1991). Autobiografia (A. Cardoso, Trad.). São Paulo: Edições Loyola (Original datado de 1555).

Lynn, R. (1991). Race differences in intelligence: a global perspective. The Mankind Quarterly, 31(3), 255-296.

Macedo, N. (1929). Memorial de Vilanova. Rio de Janeiro: O Cruzeiro.

Machado, R.; Loureiro, A.; Luz, R. \& Muricy, K. (1978). Danação da norma: a medicina social e constituição da psiquiatria no Brasil. Rio de Janeiro: Edições Graal. 
Masiero, A. L. (2002). Psicologia das raças e religiosidade no Brasil: uma intersecção histórica. Psicologia: Ciência e Profissão, 22(1), 66-79.

Masiero, A. L. (2005). A Psicologia Racial no Brasil (1918-1929). Estudos de Psicologia, 10(2), 199-206.

Massimi, M. (2003). Representações acerca dos índios brasileiros em documentos jesuítas do século XVI. Memorandum, 5, 69-85.

Massimi, M. (2005). Palavras, almas e corpos no Brasil colonial. São Paulo: Edições Loyola.

Massimi, M. (2012). A novela História do Predestinado Peregrino e de seu irmão Precito (1682) - Compêndio dos saberes antropológicos e psicológicos dos jesuítas no Brasil colonial. Em M. Massimi (Org). A Novela História do Predestinado Peregrino e de seu irmão Precito (1682) (pp. 15-56), São Paulo: Edições Loyola.

Massimi, M. (2016). História dos saberes psicológicos. São Paulo: Paulus.

Massimi, M. (2020). Psychological Knowledge in Brazilian Culture. History and Systems of Psychology. Oxford: Oxford University Press.

Medeiros, M. (1908). A questão dos methodos em Psicologia. Arquivos Brasileiros de Psychiatria, Neurologia e Medicina Legal, 4(1-2), 23-51.

Melià, B. (1990). A terra sem mal dos Guaranis. Economia e Profecia - Revista de Antropologia, 3, 34-46.

Moreira, N. J. (1868). A Questão étnico-antropológica: o cruzamento das raças acarreta a degradação intelectual e moral do produto hibrido resultante?. Biblioteca Nacional do Rio de Janeiro - Seção de Obras Raras, 264, 4,1(23), 16-17.

Morel, A. B. (2008) Acerca da conservação da espécie humana, sua propagação. Revista Latinoamericana de Psicopatologia Fundamental, 11(3), 497-501.

Mota, M. B. \& Braick, P. R. (2012). História das Cavernas ao Terceiro Milênio: do avanço imperialista no século XIX aos dias atuais. São Paulo: Editora Moderna.

Moura, C. (1964). Introdução ao pensamento de Euclides da Cunha. Rio de Janeiro: Editora Civilização Brasileira S/A.

Munanga, K. (1996). Origem e Histórico do quilombo na África. Revista USP, 28, 56-63. 
Nascimento, A. (1980). Quilombismo. Rio de Janeiro: Editora Vozes.

Oda, A. M. G. R. (2000). Nina Rodrigues e A loucura epidémica de Canudos. Revista Latinoamericana de Psicopatologia Fundamental, 3(2), 139-144.

Oliveira, R. (2002). Euclides da Cunha, Os Sertões, e a invenção de um Brasil profundo. Revista Brasileira de História, 22(44), 511-537.

Oursel, R. (1979). Pellegrini nel Medioevo: gli uomini, le strade, i santuari (A. Monti, Trad.). Milano: Jaca Book. (Original publicado em 1978).

Pereira, N. M. (1939). Compendio Narrativo do Peregrino de América. Rio de Janeiro: Edição Academia Brasileira.

Ribeiro, C. (1932). Psicologia: sua definição, seu objeto e suas divisões através de múltiplas divergências. Salvador: Arquivos Nina Rodrigues.

Romão, T. L. C. (2018). Sincretismo Religioso como estratégia de sobrevivência transacional e translacional: divindades africanas e santos católicos em tradução. Trabalhos em Linguística Aplicada, 57(1), 353-381.

Sangenis, L. F. C. (2018). O Franciscano e o Jesuíta: tradições da educação brasileira. Educação \& Realidade, 43(2), 691-709.

Santos, B. M. M. (2012). Lombroso no Direito Penal: o destino d'O Homem Delinquente e os perigos de uma ciência sem consciência. Em: CONPEDI, (pp. 7209-7229). Uberlândia: Universidade Federal de Uberlândia.

Schmitt, A., Turatti, A., Manzoli, M. C. \& Carvalho, M. C. P. (2002). A atualização do conceito de quilombo: identidade e território nas definições teóricas. Ambiente \& Sociedade, 10, 129-136.

Silva, L. L. (1931). Cruzamento do preto com branco. Boletim de Eugenia, 30(3), 3-4.

Skidmore, T. (1989) Preto no branco. Raça e nacionalidade no pensamento brasileiro (R. S. Barbosa, Trad.) Rio de Janeiro: Paz e Terra. (Original publicado em 1979).

Souza, N. P. B. \& Galvão, G. (2007). O estigma de uma obra: a trajetória de Euclides da Cunha e suas reapropiações sob o ponto de vista do positivismo e do evolucionismo. Revista da SBHC, 5(2), 173-184.

Stein, E. (1999). Psicologia e scienze dello spirito: contributi per uma fondazione filosófica (A. M. Pezzella, Trad.). Roma: Città Nuova. (Original publicado em 1970). 
Stepan T., Nancy L. (1990). Eugenics in Brazil (1917-1940). Em M. B. Adams (Org). The wellborn science, eugenics in Germany, France, Brazil and Russia, pp. 331-391. Oxford: Oxford University Press.

Tavares, O. \& Verger, P. (1947). Roteiro de Canudos - I e II: O reduto de Antônio Conselheiro. O Cruzeiro, 39(3), 9-18.

Vasconcellos, P. L. (2017). Antônio Conselheiro, por ele mesmo. São Paulo: É Realizações.

Ventura, R. (1996). Euclides da Cunha e a República. Estudos Avançados, 10(26), 275-291.

Ventura, R. (1997). Canudos como cidade iletrada: Euclides da Cunha na urbs monstruosa. Revista de Antropologia, 40(1), 165-181.

Vianna, F. J. O. (1930). Os typos eugenicos. Boletim de Eugenia, 19, 3-4.

Vianna, F. J. O. (1991). O eugenismo paulista. Em Vianna, F.J.O. Ensaios inéditos (pp. 69-73). Campinas: Editora da UNICAMP.

\section{Nota sobre os autores:}

Gabriela Daud Bollela é estudante de Psicologia na Faculdade de Filosofia Ciências e Letras de Ribeirão Preto, da Universidade de São Paulo. E-mail: gabriela.bollela@usp.br

Marina Massimi é Professora Titular aposentada da Universidade de São Paulo. Atualmente, Professora-sênior junto ao Instituto de Estudos Avançados da Universidade de São Paulo e lidera Grupo de Pesquisa Tempo, Memória e Pertencimento. E-mail: mmassimi3@yahoo.com

Data de submissão: 24.09.2019

Data de aceite: 02.03.2021 